\title{
Oxygen Consumption and Ouabain Binding Sites in Cystic Fibrosis Nasal Epithelium
}

\author{
M. J. STUTTS, M. R. KNOWLES, J. T. GATZY, AND R. C. BOUCHER \\ Departments of Medicine and Pharmacology, School of Medicine, University of North Carolina at Chapel Hill, \\ Chapel Hill, North Carolina 27514
}

\begin{abstract}
Ion transport by the epithelium lining the airways of patients with cystic fibrosis (CF) is characterized by a raised transepithelial $P D$ and an increased amiloride sensitivity (1). These properties could arise from normal sodium transport across an epithelium with decreased cell chloride permeability and limited chloride secretion. Alternatively, a higher than normal rate of sodium absorption could contribute to these abnormalities. We investigated the latter possibility by measuring oxygen consumption and specific ouabain binding of $\mathrm{CF}$ and atopic polyp epithelia and normal turbinate epithelium. Tissue from CF patients consumed oxygen at a rate that was two to three times that of non-CF tissues and had $60 \%$ more ouabain binding sites than non-CF epithelium. These results are not consistent with an isolated defect in chloride permeability but support recent findings that the sodium conductance of the apical cell membrane and net sodium absorption by $\mathrm{CF}$ nasal epithelium are greater than those of non-CF nasal epithelium. (Pediatr Res 20: 1316-1320, 1986)
\end{abstract}

\section{Abbreviations}

CF, cystic fibrosis

KBR, Kreb's bicarbonate Ringer's solution $P D$, potential difference

In $\mathrm{CF}$, ion transport by airway epithelium is markedly abnormal $(1,2)$. The lumen negative PD generated in vivo by the nasal or tracheobronchial epithelium of CF patients is 2- to 3-fold greater than that of normal or disease control individuals (1) and hyperpolarizes less in response to superfusion with a chloridefree solution (3). Parallel findings in studies of sweat gland ductal epithelium have been interpreted as evidence for reduced membrane chloride permeability that traps salt in the duct lumen (4, $5)$. The more complete inhibition of airway PD by superfused amiloride, in vivo, is also consistent with the absence of a functioning chloride secretory path in $\mathrm{CF}$ airways $(1,2)$. Others have speculated, based on this reasoning, that the functional defect in CF airway epithelia is deficient chloride conductance (4). Alternatively, the greater amiloride efficacy and raised PD in $\mathrm{CF}$ airway epithelia could reflect both a decreased chloride permeability and an increased sodium absorptive rate.

Received March 31, 1986; accepted July 31, 1986.

Correspondence to M. J. Stutts, Ph.D., Division of Pulmonary Diseases, 724 Burnett-Womack Building 229H, University of North Carolina, Chapel Hill, NC 27514.

Supported by a Research Resources Development Program Grant from the Cystic Fibrosis Foundation R002 7-04, a grant from R.J. Reynolds Tobacco Co. and NHLBI Grant HL-33474. This work was conducted during Dr. Boucher's tenure as an Established Investigator of the American Heart Association.
In epithelia that are dependent on operation of the $\mathrm{Na}^{+}-\mathrm{K}^{+}-$ ATPase for ion transport, variations in transport rate can be paralleled by changes in indices of $\mathrm{Na}^{+}-\mathrm{K}^{+}$-ATPase activity. For example, increased ATP hydrolysis and numbers of sodium pumps have been found to accompany increases in sodium absorption by renal tubules (6) and chloride secretory capacity was paralleled by pump activity in shark rectal gland (7). In dog trachea, a predominantly chloride secreting airway epithelium, inhibition of chloride secretion caused a decrease in ouabainsensitive oxygen consumption (8). We reasoned that if the defect in cell chloride permeability in CF airways caused decreased chloride secretion, then hydrolysis of ATP by the $\mathrm{Na}^{+}-\mathrm{K}^{+}-$ ATPase in CF cells would be normal or even reduced. On the other hand, if sodium absorption is increased in CF airway epithelium, then the synthesis and hydrolysis of ATP devoted to sodium pump activity should be greater than normal because of faster pump turnover and/or increased pump density. We investigated these possibilities indirectly by measuring oxygen consumption and specific ouabain binding of CF and atopic polyp epithelium and of normal turbinate epithelium.

\section{METHODS}

Sources of tissues. All tissues were obtained from material excised during nasal reconstructive surgery or polypectomies as approved by the Human Rights Committee of the University of North Carolina-CH School of Medicine. Normal turbinate epithelium was obtained from 17 patients with a mean age of 23.9 $\pm 3.0 \mathrm{yr}$ and no history of any respiratory or systemic diseases. Polyps were obtained from $10 \mathrm{CF}$ patients with a mean age of $13.4 \pm 2.6$ yr. Each was diagnosed by standard clinical criteria for CF (9). Disease control tissues were polyps that were removed from 10 atopic patients (mean age $39.2 \pm 6.5 \mathrm{yr}$ ) who had seasonal rhinitis and peripheral eosinophilia. Some $C F$ and atopic patients who had polypectomies failed to respond to courses of topical steroids which had been discontinued several weeks before surgery. Most CF patients were taking antibiotics. Some atopic patients were taking oral and inhaled bronchodilators at the time of surgery.

Tissue preparation, solutions, and drugs. Tissues were transported to the laboratory from the operating room in $37^{\circ} \mathrm{C}$ physiological salt solution (KBR) equilibrated with 95\%:5\% $\mathrm{O}_{2}: \mathrm{CO}_{2}$. KBR contained, in mMol/liter: $115 \mathrm{NaCl}, 25 \mathrm{NaHCO}_{3}$, $1.25 \mathrm{CaCl}_{2}, 1.25 \mathrm{MgCl}_{2}, 2.4 \mathrm{~K}_{2} \mathrm{HPO}_{4}, 0.2 \mathrm{KH}_{2} \mathrm{PO}_{4}$, and $5.0 \mathrm{mM}$ glucose. A layer of mucosa approximately $0.5-\mathrm{mm}$ thick was removed from the submucosa by fine dissection in $37^{\circ} \mathrm{C} \mathrm{KBR}$ that was continuously bubbled with $95 \%: 5 \% \mathrm{O}_{2}: \mathrm{CO}_{2}$. For measurements of oxygen consumption the mucosa was cut into pieces of approximately $0.5 \mathrm{~cm}^{2}$ in area. For ouabain binding studies mucosa was divided into segments that were approximately 1-mm square. All tissues were maintained in a Dubnoff shaking incubator $\left(1 \mathrm{~Hz}, 37^{\circ} \mathrm{C}, 95 \%\right.$ air: $5 \% \mathrm{CO}_{2}$ or $\left.95 \% \mathrm{O}_{2}: 5 \% \mathrm{CO}_{2}\right)$ except when mounted in Ussing chambers (see below) or re- 
moved for measurement of oxygen consumption or change of bathing solution. The experimental protocols described below were initiated within $60 \mathrm{~min}$ after surgical excision of the tissue. Ouabain and dinitrophenol (Sigma Chemical Company, St Louis, MO) were dissolved in water and dimethylsulfoxide, respectively. Amiloride $\mathrm{HCl}$ was dissolved in $\mathrm{KBR}$.

Measurement of oxygen consumption. After $60 \mathrm{~min}$ of incubation in KBR individual tissues were sealed in a chamber $(2.0$ $\mathrm{ml}$ volume) with a polarographic oxygen electrode (Yellow Springs Instruments, Yellow Springs, $\mathrm{OH}$ ). The electrode output was calibrated to read $100 \%$ in a solution which had been equilibrated in air and $5 \% \mathrm{CO}_{2}$ at $37^{\circ} \mathrm{C}$ and was recorded on a strip chart recorder as percent oxygen content. Two to four pieces of mucosa from each patient were studied. Tissues were exposed to stock drug solutions that were diluted 1:333 directly into the $2.0 \mathrm{ml}$ bath with the tissue after a basal rate of oxygen consumption had been recorded for at least 5 min. A new steady state of oxygen consumption was reached within $5 \mathrm{~min}$. These rates were found to be no different from those measured in experiments where the oxygen consumption after $30 \mathrm{~min}$ of drug exposure was compared to that of time controls. Preliminary experiments established the smallest concentration of each agent that caused the maximal change in oxygen consumption. This concentration was used in all subsequent experiments. The rate at which $\mathrm{O}_{2}$ was consumed was estimated from the strip chart recordings and the $\mathrm{O}_{2}$ content of $2.0 \mathrm{ml}$ of $\mathrm{KBR}$ saturated with air:5\% $\mathrm{CO}_{2}$ at $37^{\circ} \mathrm{C}$ (approximately $10.0 \mu \mathrm{l}$, depending on ambient barometric pressure). After the last determination of oxygen consumption, each tissue was blotted on moistened filter paper, placed on a preweighed aluminum pan, dried overnight at $95^{\circ} \mathrm{C}$, and reweighed. In the earliest experiments we measured only dry weight. Later, we also determined the DNA content of dried tissues colorimetrically from the absorbance of hot trichloroacetic acid extracts at $540 \mathrm{~nm}$ (10). Calf thymus DNA (type 1, Sigma) was used as a standard.

Ouabain binding. The number of $\mathrm{Na}^{+}-\mathrm{K}^{+}$-ATPase sites in nasal epithelium was estimated from the steady state of binding of ${ }^{3} \mathrm{H}$-ouabain to segments of nasal polyp or turbinate. The technique is similar to that described by Mills et al. (11) and applied by Widdicombe et al. (12) to the study of canine tracheal epithelium. Nasal mucosal segments, approximately $0.5 \mathrm{mg}$ wet weight, were incubated with ${ }^{3} \mathrm{H}$-ouabain (New England Nuclear, Boston, MA, $20 \mathrm{Ci} / \mathrm{mmol}$, diluted to $10 \mathrm{nM}$ ) which was diluted or combined with nonradioactive ouabain to provide a range of total ouabain concentrations of 1 to $1000 \mathrm{nM}$. In preliminary experiments, binding was shown to reach steady state levels in 60-120 min. Subsequent incubations were carried out for 120 $\mathrm{min}$. This was followed by a wash period of $60 \mathrm{~min}$ during which the tissues were exposed to KBR alone. This period was shown, in separate experiments, to be sufficient for the tissues to be washed free of the extracellular marker, ${ }^{14} \mathrm{C}$-mannitol. After the wash, each tissue was blotted on moistened filter paper, weighed, and extracted overnight in a glass scintillation vial containing $300 \mu \mathrm{l}$ of tissue solubilizer (Protosol, New England Nuclear). The mixture was neutralized with glacial acetic acid, combined with $9.0 \mathrm{ml}$ of scintillation cocktail (Aquasol II, New England $\mathrm{Nu}-$ clear) and assayed for ${ }^{3} \mathrm{H}$-activity. Aliquots of each incubation solution were extracted and counted in the same way. Nonspecific ouabain binding was taken as the ${ }^{3} \mathrm{H}$-activity associated with mucosal segments exposed to $10 \mathrm{nM}^{3} \mathrm{H}$-ouabain in the presence of $10^{-3} \mathrm{M}$ chemical ouabain. Nonspecifically associated ${ }^{3} \mathrm{H}$ activity (typically less than $3 \%$ of the total measured at 10 $\mathrm{nM}$ ) was subtracted from the binding of ${ }^{3} \mathrm{H}$-ouabain measured at $10-1000 \mathrm{nM}$ total ouabain concentration. In some experiments we measured the binding of ouabain to pieces of submucosa from which the epithelium had been removed by fine dissection. The binding of ${ }^{3} \mathrm{H}$-ouabain was determined in two to four pieces of mucosa at each concentration and the results were averaged for each patient. Specific ouabain binding was normalized for wet weight.
Short-circuit current inhibition. Pieces of normal turbinate or CF polyp were mounted in Ussing chambers and net ion transport was assessed as short circuit current, as described previously (13). After a 45- to 60 -min period for stabilization of bioelectric properties, ouabain was added to the submucosal bathing solution to a final concentration of $10^{-7}-10^{-5} \mathrm{M}$. Short circuit current was monitored for an additional $120 \mathrm{~min}$ or until abolished.

Analysis of data. When an experiment was replicated with tissues from the same patient, the results were averaged so that $n$ refers to numbers of patients. Results are expressed as the mean \pm SEM. The statistical significance of differences between means was assessed by paired or unpaired $t$ analysis (14). Ouabain binding data were treated by the method proposed by Scatchard (15). The best fit lines of the plots for CF and non-CF data were tested for parallelism and common intercept (16). Differences were considered significant if $p<0.05$.

\section{RESULTS}

Oxygen consumption. The tissues used in these studies were surgically derived, so it was not possible to study perfectly agematched controls or obligate $\mathrm{CF}$ heterozygotes. The oxygen consumption of pieces of nasal mucosa from three groups of patients is plotted as a function of patient age in Figure 1. There is no overlap between $C F$ and non-CF groups, whereas the normal and atopic group overlap completely. There was no significant relationship between oxygen consumption and age for any group.

Regional variations in turbinate epithelial morphology could influence the comparison of oxygen consumption by CF polyp and normal nasal epithelium. Accordingly, atopic polyps were regarded as a "control" that might help determine the contribution of morphology to differences between CF polyp and normal turbinate mucosa. In addition, because differences in epithelial morphology could influence the number of cells per unit dry weight, we measured the DNA content of most of our samples. The results are shown in Figure 2. Because CF tissues were in demand for other studies and consumed oxygen at a higher rate than non-CF tissues, the size of $C F$ specimens tended to be smaller. A regression line fit to all the points had a slope of 30.2 $\mu \mathrm{g}$ DNA per mg dry weight with a correlation coefficient of 0.92 .

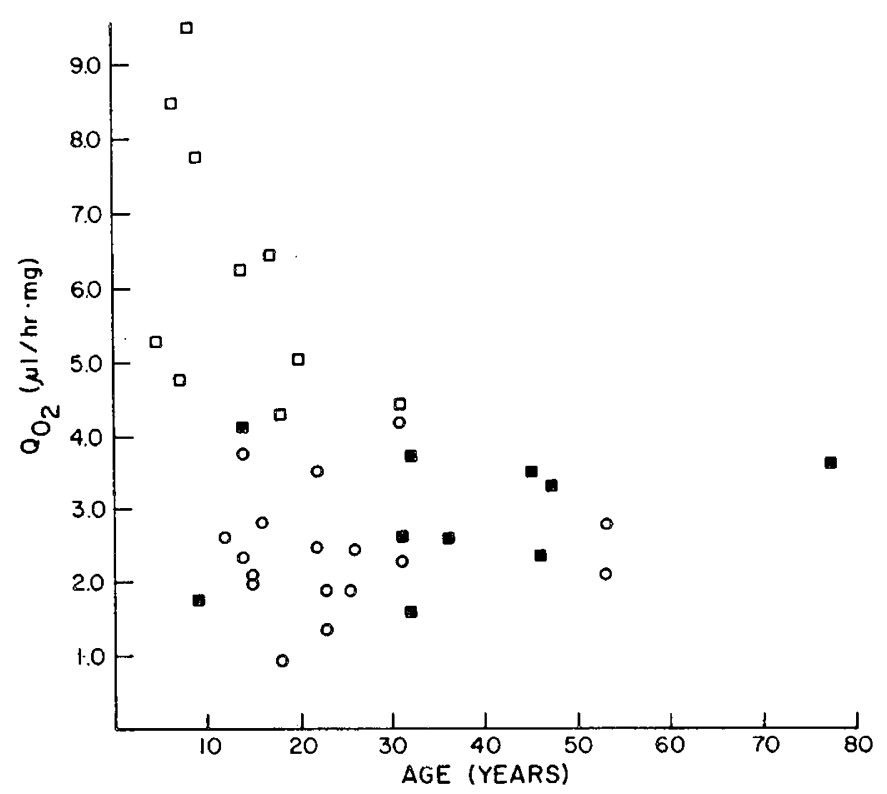

Fig. 1. Oxygen consumption by nasal mucosa from normal (O),

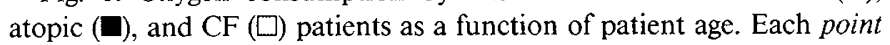
represents the average rate of oxygen consumption of from two to four tissue samples from a single patient. 


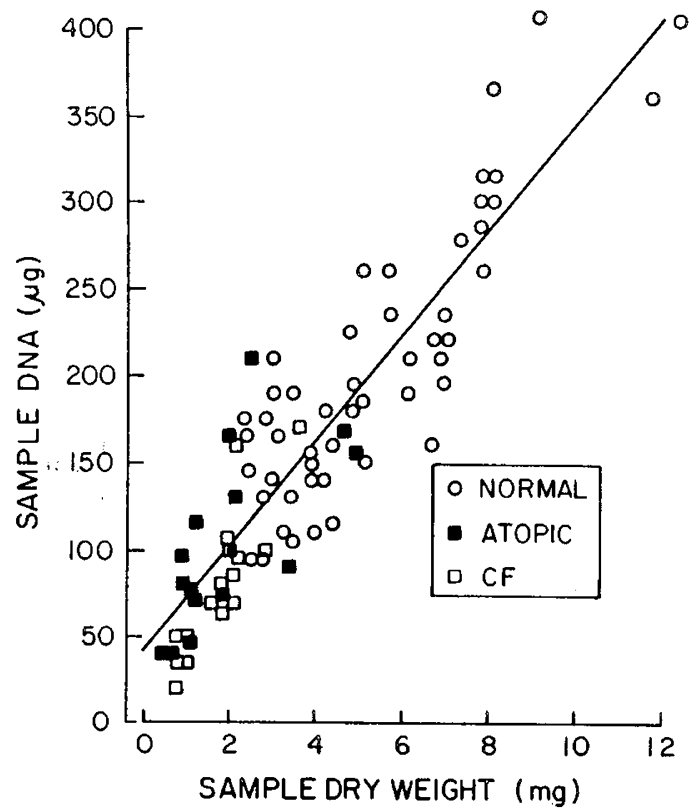

Fig. 2. Sample DNA as a function of sample dry weight. Each point is the average of duplicate DNA determinations.

Table 1. Oxygen consumption of mucosa from normal turbinates and atopic and CF nasal polyps (mean $\pm S E M$ )

\begin{tabular}{ccc}
\hline Normal & Atopic & CF \\
\hline$\mu 1 \mathrm{O}_{2} / \mathrm{mg}$ dry wt/h & & \\
$2.4 \pm 0.2$ & $3.0 \pm 0.3$ & $6.22 \pm 0.6^{*}$ \\
$(n=17)$ & $(n=10)$ & $(n=10)$ \\
& & \\
$\mu \mathrm{l} \mathrm{O} / \mu \mathrm{g} \mathrm{DNA} / \mathrm{h}$ & & \\
$0.056 \pm 0.005$ & $0.062 \pm 0.009$ & $0.146 \pm 0.017^{*}$ \\
$(n=11)$ & $(n=6)$ & $(n=7)$ \\
\hline
\end{tabular}

* Different from normal or atopic $(p<0.001)$.

Table 2. Pharmacologic characterization of nasal mucosal oxygen consumption (\% inhibition of control rate)

\begin{tabular}{lccc}
\hline & Normal & Atopic & CF \\
\hline Ouabain & & & \\
$\left(3 \times 10^{-5} \mathrm{M}\right)$ & $(n=17)$ & $(n=9)$ & $(n=10)$ \\
$\quad \%$ inhibition & $31.5 \pm 2.6$ & $40.4 \pm 6.0$ & $40.7 \pm 3.4$ \\
$\mu \mathrm{l} / \mathrm{mg} / \mathrm{h}$ & $0.77 \pm 0.09$ & $1.16 \pm 0.13$ & $2.43 \pm 0.24^{*}$ \\
& & & \\
Amiloride & & & \\
$\left(3 \times 10^{-5} \mathrm{M}\right)$ & $(n=17)$ & $(n=9)$ & $(n=8)$ \\
$\%$ inhibition & $13.1 \pm 2.8$ & $14.7 \pm 4.7$ & $21.4 \pm 1.9$ \\
$\mu \mathrm{l} / \mathrm{mg} / \mathrm{h}$ & $0.30 \pm 0.07$ & $0.37 \pm 0.10$ & $1.20 \pm 0.12^{*}$ \\
& & & \\
DNP & & & \\
$\left(10^{-4} \mathrm{M}\right)$ & $(n=9)$ & $(n=6)$ & $(n=7)$ \\
$\%$ increase & $44.6 \pm 16.1$ & $46.2 \pm 18.0$ & $65.1 \pm 25.0$ \\
$\mu \mathrm{l} / \mathrm{mg} / \mathrm{h}$ & $1.05 \pm 0.38$ & $1.45 \pm 0.58$ & $3.39 \pm 1.35$ \\
\hline
\end{tabular}

* Different from normal or atopic $(p<0.001)$.

Consequently, dry weight appears to be an adequate estimate of cell number. Most of the CF tissues fall below the regression line suggesting that, if anything, pieces of CF nasal mucosa contained fewer, rather than more cells, per unit dry weight.

The basal rates of oxygen consumption by mucosa from normal, atopic, and CF patients are reported in Table 1. Tissue from CF patients consumed oxygen at a rate that was two to three times that of non-CF tissues, regardless of whether the rate was expressed in terms of dry weight or per $\mu \mathrm{g}$ DNA.
The effects of ouabain, amiloride, and dinitrophenol on oxygen consumption are summarized in Table 2 . Ouabain, $3 \times 10^{-5}$ $\mathrm{M}$, inhibited oxygen consumption by 30 to $40 \%$. Although the fractional change induced by ouabain was similar for tissues from the three groups, the absolute inhibition of oxygen consumption was two to three times larger in $C F$ than in non-CF tissues. The fractional inhibition of oxygen consumption caused by amiloride tended to be greater in CF tissues, but the difference was not significant. This tendency, and the higher basal rate in $\mathrm{CF}$ tissues, however, made the absolute decrease in oxygen consumption induced by amiloride in CF tissues disproportionately (three to four times) greater than in non-CF tissues. We also exposed tissues to dinitrophenol, an agent that stimulates respiration by uncoupling mitochondrial substrate oxidation from ADP phosphorylation (17) to determine if a portion of the raised oxygen consumption in $\mathrm{CF}$ was due to uncoupled respiration. We assumed that the oxygen consumption in the presence of dinitrophenol was an index of maximum metabolic capacity. Tissues from all three sources responded to dinitrophenol with about the same fractional increase in $\mathrm{QO}_{2}$.

Ouabain binding. Figure 3 shows the specific binding of ouabain to nasal epithelium from CF $(n=10)$, atopic $(n=7)$, and normal $(n=9)$ patients. There was no difference at any ouabain concentration between binding to normal turbinate and atopic polyp epithelium, and these data were combined to represent non-CF tissue. The data are characterized by a large amount of scatter but the binding to the CF tissue was consistently greater. The binding curves are S-shaped, a characteristic of saturable bimolecular reactions. Nonspecific binding of ouabain was often indistinguishable from background and never exceeded $5 \%$ of the counts associated with the washed tissues at any ouabain concentration. In terms of wet weight, pieces of submucosa from which the epithelial surface had been dissected had only about $10 \%$ of the specific ${ }^{3} \mathrm{H}$-ouabain binding measured in the mucosal segments. Scatchard analysis of the data in Figure 3 results in the plots shown in Figure 4. The CF data are described by a line with a correlation coefficient of 0.88 and an intercept on the

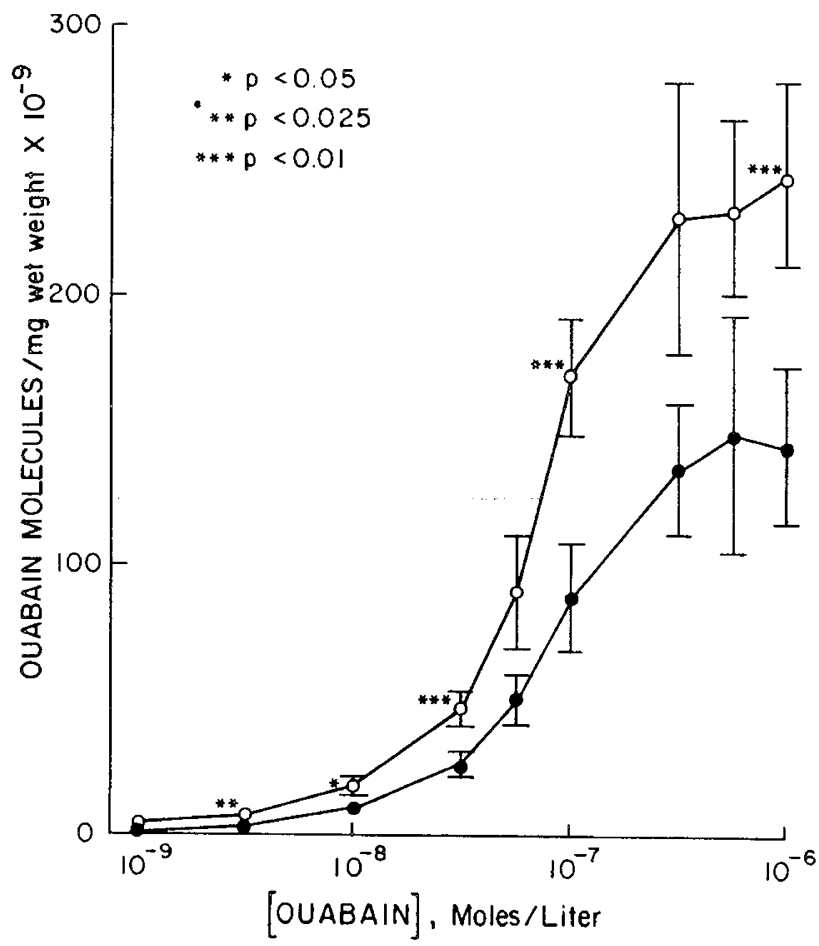

Fig. 3. Ouabain binding to $\mathrm{CF}$ and non-CF nasal epithelium. Total binding as a function of free ouabain concentration to $\mathrm{CF}(\mathrm{O})(n=10)$ and non-CF $(\bullet)(n=16)$ nasal mucosa. 


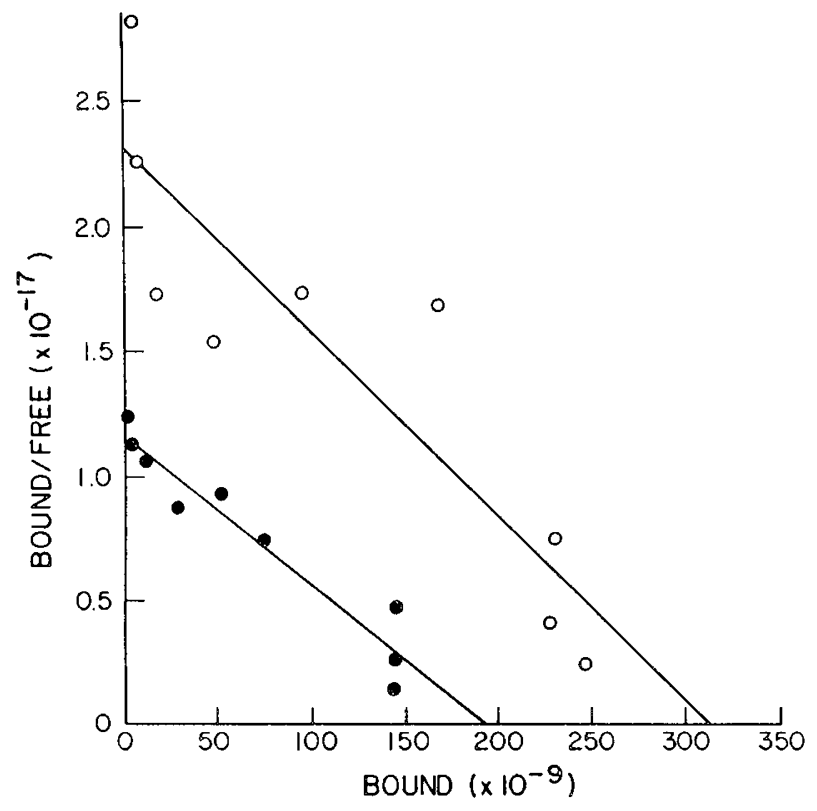

Fig. 4. Ouabain binding to $\mathrm{CF}$ and non-CF nasal epithelium. Scatchard transformation of the data in Figure 3. Symbols as in Figure 3.

abscissa of $313 \times 10^{9} \mathrm{M}$ sites per mg wet weight. The non-CF data are fitted by a line with a correlation coefficient of 0.97 and an intercept of $193 \times 10^{9}$ sites per mg wet weight (different from $\mathrm{CF}, p<0.05)$. The slopes of the two lines are not different $(p>$ $0.5)$. The apparent $\mathrm{K}_{\mathrm{m}} \mathrm{s}$ calculated from the slopes are $1.4 \times 10^{-7}$ and $1.7 \times 10^{-7} \mathrm{M}$ for $\mathrm{CF}$ and non-CF tissue, respectively. These values do not differ from each other and are similar to that obtained by Widdicombe et al. (12) from ouabain binding to canine tracheal epithelium.

Short circuit current inhibition. Ouabain inhibits $\mathrm{Na}^{+}-\mathrm{K}^{+}$ATPase activity in many tissues with diverse functions (18). In airway epithelia the action of the $\mathrm{Na}^{+}-\mathrm{K}^{+}$-ATPase supports both sodium absorption and chloride secretion $(8,19)$. Short circuit current, an index of active ion transport, was inhibited $17.0 \pm$ $2.0 \%(n=3)$ in non-CF and $17.0 \pm 1.9 \%(n=3)$ in CF tissues by $10^{-7} \mathrm{M}$ ouabain after $120 \mathrm{~min}$. With $10^{-6} \mathrm{M}$ ouabain, short circuit current was nearly completely inhibited within $60 \mathrm{~min}$ in both CF $(88.8 \pm 4.4 \%, n=4)$ and non-CF tissues $(91.0 \pm 1.3 \%$, $n=3$ ). Complete inhibition was obtained even more rapidly with $10^{-5} \mathrm{M}$ ouabain. Accordingly, the binding represented in Figure 3 appears to represent the interaction of ouabain with a high affinity site over the range of concentrations inhibitory for ion transport in vitro.

\section{DISCUSSION}

The results summarized in Table 1 demonstrate that the basal oxygen consumption of excised CF nasal polyp epithelium is two to three times that of normal turbinate epithelium and atopic polyp epithelium. Although nasal epithelial morphology varies with region, the morphologic similarity of atopic and CF polyps (20) makes it unlikely that morphologic heterogeneity can account for this difference. Moreover, the different rate of oxygen consumption was not related to patient age (Fig. 1) or to a difference in the cell density (DNA) in mucosal specimens from the different patient groups (Fig. 2). Accordingly, the more than 2 -fold larger oxygen consumption of CF tissues appears to be a manifestation of the disease.

Approximately $30-40 \%$ of basal oxygen consumption by nasal mucosa was linked by ouabain inhibition to generation of ATP that is utilized by the $\mathrm{Na}^{+}-\mathrm{K}^{+}$-ATPase (Table 2). Because both sodium absorption and chloride secretion are driven by the action of the $\mathrm{Na}^{+}-\mathrm{K}^{+}$-ATPase in airway epithelia (19), ouabainsensitive oxygen consumption should be an index of these transport activities (8). Under basal conditions, approximately $80 \%$ of normal nasal epithelial short circuit current is due to net sodium absorption (13). Thus, if CF nasal mucosa differed from normal solely by a defect in chloride permeability that prevented chloride secretion, then a small reduction in oxygen consumption would be predicted. In agreement with this notion, we found in preliminary experiments that bumetanide, an inhibitor of chloride secretion, reduced oxygen consumption of normal tissues by only $7.6 \pm 0.5 \%(n=11)$. Accordingly, the finding that ouabain-sensitive oxygen consumption was two to three times greater in CF than in atopic polyp or normal turbinate epithelium suggests a more complicated defect in ion transport than the absence of chloride secretion.

Amiloride should limit sodium entry into cells across the apical membrane (21). If this were the only route of sodium entry, then the effect of amiloride on oxygen consumption should be similar in magnitude to that of ouabain. Inhibition of oxygen consumption by amiloride was less than that by ouabain, regardless of tissue group (Table 2), implying that other routes for sodium entry, including the basolateral cell membrane cotransport system, sodium for proton exchange, nonspecific ion leaks, etc, exist in both $\mathrm{CF}$ and non-CF tissues. The larger inhibition of oxygen consumption by amiloride in CF tissues can be interpreted in terms of two recent findings. First, $\mathrm{CF}$ tissues lack the ability to secrete chloride (13). In CF tissues, therefore, amiloride cannot stimulate the coupled entry of sodium and chloride required for the chloride secretion that is induced in normal tissues exposed to amiloride $(2,13)$. This difference in response could underlie the tendency for a proportionately larger amiloride inhibition of oxygen consumption in CF tissues. However, because the amiloride-sensitive oxygen consumption in $\mathrm{CF}$ tissues exceeded the total ouabain-sensitive oxygen consumption of normal tissues, decreased chloride permeability cannot account for the entire increment in amiloride-sensitive oxygen consumption seen in $\mathrm{CF}$ tissues. Instead, the larger response to amiloride is likely related to our recent finding that the sodium conductance of the apical membrane of CF nasal epithelial cells is increased (22). The three to four times larger amiloride-sensitive oxygen consumption in CF tissues is consistent with the notion that a greater quantity of substrate for the $\mathrm{Na}^{+}$pump enters CF cells through an amiloride-sensitive path. Thus, the greater effect of amiloride in CF tissues is compatible with both a decreased chloride conductance (22-24) and an increased sodium conductance in the apical cell membrane (22).

The effects of ouabain and amiloride on oxygen consumption demonstrate coupling between metabolism and ion transport but the quantity of oxygen consumption not sensitive to these inhibitors of ion transport was also raised in CF tissues. This increment in ouabain-insensitive oxygen consumption in CF represents coupled respiration, however, because DNP raised total oxygen consumption by similar relative amounts in normal, atopic, and CF nasal epithelium (Table 2). These data are consistent with the existence of a greater metabolic capacity in CF cells. Previous investigators have noted that mitochondria derived from $\mathrm{CF}$ fibroblasts consumed oxygen more rapidly than mitochondria derived from normal fibroblasts (25). This difference was associated with increased $\mathrm{Ca}^{++}$uptake by $\mathrm{CF}$ fibroblast mitochondria (26) and an altered $\mathrm{pH}$ optimum of the mitochondrial $\mathrm{NADH}$ dehydrogenase (25). We have not explored the relationship of these findings to our results.

The characteristics of ouabain binding to nasal epithelial cells were similar to those described for specific ouabain binding in other systems $(7,12)$. In particular, the binding of ${ }^{3} \mathrm{H}$-ouabain was specific by two criteria (18). First, it was prevented by an excess of unlabeled ouabain. Second, specific binding saturated in the range of ouabain concentrations which inhibit ion transport in vitro (Fig. 3) (see "Results"). Scatchard analysis of the binding data yielded straight lines (Fig. 4) with apparent $K_{M} S$ 
which were not different for the two populations and were about half of the estimated $\mathrm{K}_{\mathrm{i}}$ s for ouabain inhibition of short circuit current. Similar correlations between binding and inhibition of function have been found for dog tracheal epithelium (12) and other tissues $(7,11)$. The intercepts of the Scatchard plots project about $60 \%$ more ouabain binding sites $\left(\mathrm{Na}^{+}\right.$pumps) in $\mathrm{CF}$ epithelium than non-CF epithelium. The density of ouabain binding sites, although raised, was not increased as much as net sodium absorption (27) or ouabain-sensitive oxygen consumption (this study). The implication that the activity of each ouabain binding site in $\mathrm{CF}$ is also increased merits further study.

The cause of the increased oxygen consumption and ouabain binding sites of $\mathrm{CF}$ airway epithelium cannot be inferred from these in vitro studies. However, several aspects of the chronic nature of the disease and the clinical status of CF patients can be addressed. For example, although we did not measure serum aldosterone concentrations of the patients from whom tissue was obtained, some CF patients have had increased serum concentrations of aldosterone that result from salt wasting through eccrine sweat (28). Aldosterone is known to affect the sodium absorption of several epithelia by actions that result in an increased rate of oxidative metabolism and increased rate of active sodium transport (29). We previously found, however, that aldosterone secretion is not routinely raised in CF patients, and that ion transport by airway epithelium is unaffected by changes in aldosterone excretion (30). Salt and water absorption by some epithelia and tissue oxidative metabolism are also stimulated by thyroid hormones (31). Although there is an excess incidence of goiter in CF patients exposed to an iodide load, the basis of this effect is not known and circulating concentrations of $\mathrm{T}_{3}$ are normal or decreased (32). As a control for the polyp tissues studied in CF patients, polyps from atopic subjects were studied. Atopic polyps differ from CF histologically only in the greater content of eosinophils (20). We found that atopic polyp mucosa did not differ from normal tissue in oxygen consumption or ouabain binding sites. In addition, recent studies have shown that the nasal PD measured in the first $48 \mathrm{~h}$ of life is raised suggesting that sodium absorption is increased prior to the onset of chronic infection and inflammation (33). Thus, raised aldosterone secretion, abnormal thyroid function, or chronic inflammatory status in the CF patient group are not likely explanations for our results.

CF nasal polyp epithelium has been previously characterized as less permeable to chloride ion $(3,13)$. This defect was shown to be located in the apical cell membrane (22) and to be retained in cell culture (23). More recent studies reveal abnormal sodium transport, including a greater net (active) sodium absorption by CF airway epithelium (27) that correlates with a greater sodium ionic conductance of the apical cell membrane (22). The present study demonstrates increased density of sodium pumps and increased ouabain and amiloride-sensitive oxygen consumption of CF airway epithelium. These findings support the other observations that $\mathrm{CF}$ is expressed in airways as both 1) a greater than normal rate of active sodium transport and 2) an inability to secrete chloride. These abnormal functions could represent a primary defect in regulation and/or a mixture of a primary defect (chloride impermeability?) and a secondary response (increased sodium absorption?). Regardless of primacy, both defects might lead to dehydration of mucins and other macromolecules on the airway surface and thereby contribute to the pathophysiology of obstructive lung disease in $\mathrm{CF}$.

Acknowledgment. Amiloride $\mathrm{HCl}$ was a gift of the Merck, Sharpe and Dohme Division of Merck Inc., Rahway, NJ.

\section{REFERENCES}

1. Knowles MR, Gatzy JT, Boucher RC 1981 Increased bioelectric potential difference across respiratory epithelia in cystic fibrosis. $\mathbf{N}$ Engl $\mathbf{J}$ Med 305:1489-1495

2. Boucher RC, Knowles MR, Stutts MJ, Gatzy JT 1983 Epithelial dysfunction in cystic fibrosis lung disease. Lung 161:1-17

3. Knowles MR, Gatzy JT, Boucher RC 1983 Relative ion permeability of normal and cystic fibrosis nasal epithelium. J Clin Invest 71:1410-1417

4. Bijman J 1983 Short communication: decreased $\mathrm{Cl}$ permeability as the basis for increased bioelectrical potentials in cystic fibrosis. Pediatr Res 17:701702

5. Quinton PM, Bijman J 1983 Higher bioelectric potentials due to decreased chloride absorption in the sweat glands of patients with cystic fibrosis. $\mathrm{N}$ Engl J Med 308:1185-1188

6. Rayson BM, Gupta RK 1985 Steroids, intracellular sodium levels and $\mathrm{Na}^{+}$/ $\mathrm{K}^{+}$-ATPase regulation. J Biol Chem 260:12740-12743

7. Silva P, Epstein JA, Stevens A, Spokes K, Epstein FH 1983 Ouabain binding in rectal gland of Squalus acanthias. J Membrane Biol 75:105-114

8. Welsh MJ 1984 Energetics of $\mathrm{Cl}^{-}$secretion in canine tracheal epithelium. J Clin Invest 74:262-268

9. Wood RE, Boat TF, Doershuk CF 1976 Cystic fibrosis. Am Rev Respir Dir 113:833-878

10. Burton K 1968 Determination of DNA concentration with diphenylamine. In Grossman L, Moldave K (eds) Methods of Enzymology, Vol XII. Academic Press, Orlando, FL, pp 163-166

11. Mills JW, Ernst SA, DiBona DR 1977 Localization of $\mathrm{Na}^{+}$pump sites in fro skin. J Cell Biol 73:88-110

12. Widdicombe $\mathbf{J H}$, Basbaum CB, Lee JY 1979 Localization of $\mathrm{Na}^{+}$pumps in the tracheal epithelium of the dog. J Cell Biol 82:380-390

13. Knowles MR, Stutts MJ, Spock A, Fisher NL, Gatzy JT, Boucher RC 1983 Abnormal ion permeation through cystic fibrosis respiratory epithelium. Science 221:1067-1070

14. Snedecor GW, Cochran WG 1967 Statistical Methods, 6th ed. Iowa State University Press, Ames, IA

15. Goldstein A, Aronow L, Kalman SM 1974 Principles of Drug Action. Wiley Press, New York, NY

16. Kleinbaum DG, Kupper LL 1978 Applied Regression Analysis and Other Multivariate Methods. Duxbury Press, North Scituate, MA

17. White A, Handler P, Smith E 1973 Principles of Biochemistry. McGraw-Hill, New York, NY

18. Erdman E 1981 Influence of cardiac glycosides on their receptor. In: Born GVR, Farah A, Herkin H, Welsh AD (eds) Handbook of Experimental Pharmacology, Vol 56/I. Springer-Verlag, Berlin

19. Frizzell RA, Welsh MJ, Smith PL 1981 Hormonal control of chloride secretion by canine tracheal epithelium: an electrophysiologic analysis. Ann NY Acad Sci 392:558-590

20. Oppenheimer EHJ, Rosenstein BJ 1979 Differential pathology of nasal polyps in cystic fibrosis and atopy. Lab Invest 40:445-449

21. Cuthbert AW, Shum WK 1974 Binding of amiloride to sodium channels in frog skin. Mol Pharmacol 10:880-891

22. Cotton CU, Stutts MJ, Knowles MR, Gatzy JT, Boucher RC 1985 Abnormal apical cell membrane in cystic fibrosis nasal epithelium. Clin Res 33:463A(abstr)

23. Stutts MJ, Cotton CU, Yankaskas JR, Cheng E, Knowles MR, Gatzy JT, Boucher RC 1985 Chloride uptake into cultured airway epithelial cells from cystic fibrosis patients and normal individuals. Proc Natl Acad Sci USA 82:6677-6681

24. Widdicombe JH, Welsh MJ, Finkbeiner WE 1985 Cystic fibrosis decreases the apical membrane chloride permeability of monolayers by cells cultured from tracheal epithelium. Proc Natl Acad Sci USA 82:6167-6171

25. Shapiro BL, Feigal RJ, Lam LF 1979 Mitochondrial NADH dehydrogenase in cystic fibrosis. Proc Natl Acad Sci USA 76:2979

26. Feigal RJ, Shapiro BL 1979 Mitochondrial calcium uptake and oxygen consumption in cystic fibrosis. Nature 278:276

27. Boucher RC, Stutts MJ, Knowles MR, Cantley L, Gatzy JT $1985 \mathrm{Na}^{+}$transport in cystic fibrosis nasal epithelia: abnormal basal rate and response to adenylate cyclase activation. Clin Res 33:467A(abstr)

28. Schwartz RH, Milner MR 1984 In: Taussig M (ed) Cystic Fibrosis. ThiemeStratton, New York, NY

29. Law PY, Edelman IS 1978b Induction of citrate synthase by aldosterone in the rat kidney. J Membr Biol 41:41-64

30. Knowles MR, Gatzy JT, Boucher RC 1985 Aldosterone metabolism and transepithelial potential difference in normal and cystic fibrosis subjects. Pediatr Res 19:676-679

31. Ismail-Beigi F, Edelman IS 1978 Mechanism of thyroid calorigenesis: role of active sodium transport. Proc Natl Acad Sci USA 67:1071-1078

32. Segall-Blank M, Vagenakis AG, Schwachman H, Ingbar SH, Braverman LE 1981 Thyroid gland function and pituitary TSH reserve in patients with cystic fibrosis. J Pediatr 98:218-222

33. Gowen CW, Lawson EE, Gingras-Leatherman J, Boucher RC, Knowles MR 1986 Increased nasal potential difference and amiloride sensitivity in neonates with cystic fibrosis. Pediatr Res 19:405 